\title{
Introducing Seattle A city and people pushing the edge
}

M arch 12-15, 2009, the 14th ACRL National Conference will be held in Seattle. Situated on the edge of Puget Sound and nestled between the Cascade and Olympic mountains, Seattle is surrounded by natural beauty and is at the cutting edge of business and technology. The conference theme, "Pushing the Edge: Engage, Explore, and Extend," is not only an invitation to examine present and future trends of academic libraries, but it is also an opportunity to learn about Seattle's unique histoings, culture,

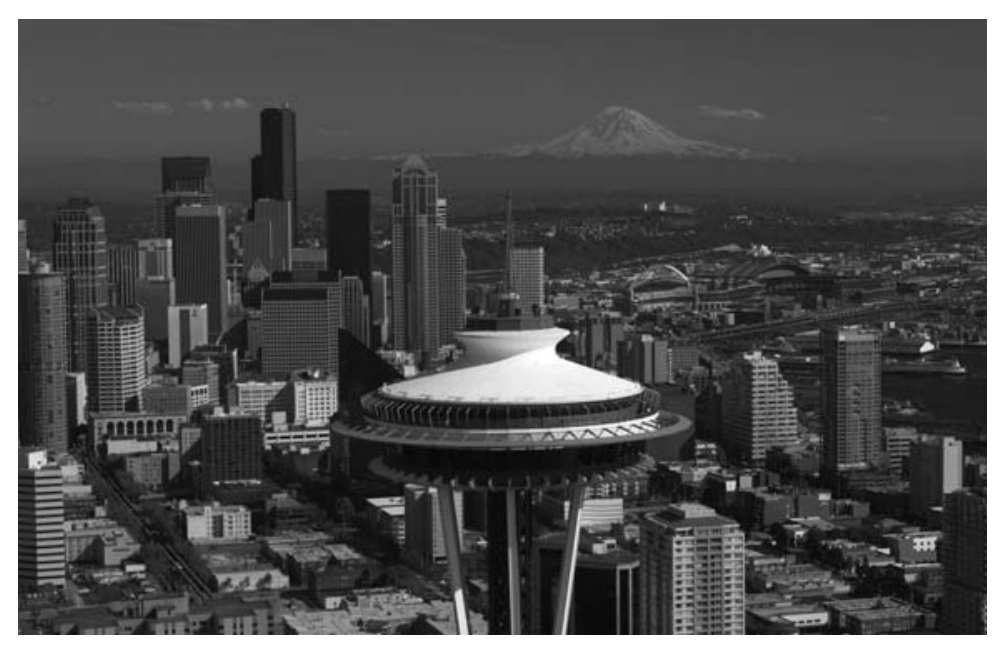

Seattle's Space Needle and Mt. Rainier, courtesy Seattle Municipal Archives, item \#114444. ry, surround-

its cities (Issaquah, Chehalis, Puyallup) and rivers (Duwamish, Snoqualmie, Queets). In the 1830s the establishment of commercial trading posts and missions throughout the territory would soon lead to settlers making their way west via the Oregon Trail. One of the first settlers in the Washington Territory was a man of color by the name of George Washington Bush. Bush came west with his family in search of freedom. But upon the inception of racial exclusion acts set in place to prevent African Ameriand people. The theme is also a metaphor for Seattle itself, a city that has continued to rebuild and reinvent itself throughout its history, always pushing the edge-now and in the past. Indeed, local historian Murray Morgan once wrote that early Seattle pioneers and their descendents "had a lot in common: confidence, energy, foresight, and most importantly a willingness to plunge." ${ }^{1}$ It is that entrepreneurial and visionary spirit that makes this city the vital place it is today.

\section{The early years}

Centuries before the settlers came, the Pacific Northwest was inhabited by a number of indigenous tribes. A reminder of this rich native heritage is found in the names of many of cans, Asians, and others from settlement in the Oregon Territory, he moved into the wilderness north of the Columbia River (the current border between Washington and Oregon), where laws were less likely to be enforced. In 1845 he set up a homestead, leading the way for other pioneers to follow further north to what would eventually become Seattle. ${ }^{2}$

The City of Seattle has a relatively brief history and is a young city even by West Coast

Jan Hartley is head of technical services at Seattle University's A. A. Lemieux Library, e-mail: hartleyj@seattleu.edu, and Elinor Appel is faculty librarian at North Seattle Community College, e-mail: eappel@sccd.ctc.edu

๑ 2008 Jan Hartley and Elinor Appel 
standards. Seattle's story of settlement begins in November 1851 with the landing at Alki Point (the current West Seattle) of the Denny Party, a group of eight adults and twelve children led by Arthur Denny. By the spring of 1852, seeking protection from the harsh wind and rain of Puget Sound, the party headed further inland to Elliott Bay and settled in the area now known as Pioneer Square. Together with Arthur Denny, Seattle's early founding fathers David "Doc" Maynard, Henry Yesler, and Asa

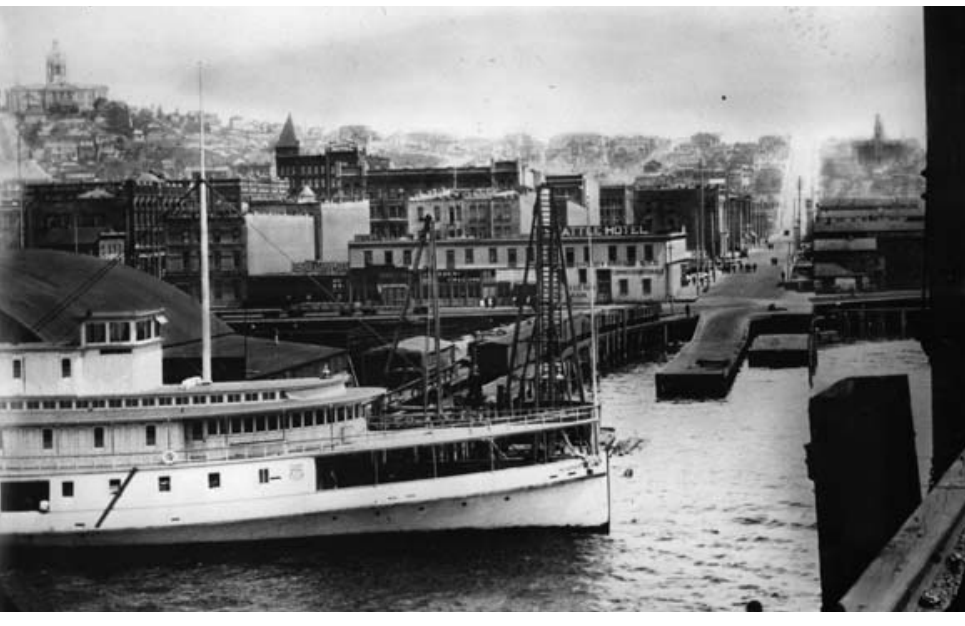

Pioneer Square from the Waterfront, c. 1896, courtesy Seattle Municipal Archives, item \# 29984. city center, built from the plentiful supply of Northwest timber, were razed in a fire set by a self-igniting pot of glue. Seattleites vowed to rebuild the city, this time in less-flammable brick and stone. Many of these early buildings still stand in and near Seattle's Pioneer Square District. In 1897 the fortune of the city would take a remarkable turn due to events hundreds of miles up north when gold was struck in the Yukon River. In an impressive marketing move, Seattle cleverly labeled itself the "Gateway to the Goldfield." Out of the estimated 100,000 "stampeders," some 70,000 were outfitted with their one year's worth of required provisions in Seattle. ${ }^{3}$ Needless to say, Seattle struck gold not only in providing supplies, but by encouraging those coming back from the Yukon to stay in Seattle and spend their money in stores, bars, and brothels. Many also stayed to build a city.

\section{On the map}

Throughout the early 20th century Seattle faced the normal growing pains and struggles of most emerging cities. Immigrant populations, mainly from China, Japan, and the Philippines, encountered discrimination, angry mobs, and violence. Active labor unions resulted in multiple strikes and protests, including the 1916 Everett Massacre and the Seattle General Strike of 1919. Seattleites suffered through the Depression with the rest of the nation. The now-common terms skid row (from the logging practice of "skidding" timber along a track or road made of logs) and Hooverville (a 1931 shantytown) both are said to have originated in Seattle. During World War II Seattle's Japanese community, 
many of whom were American citizens, were forcibly removed from their homes, lost their businesses, and were interned in rudimentary camps, such as Camp Harmony, in nearby Puyallup, Washington.

During this time other events and individuals made more positive contributions to the city. Seattle Public Library opened its first downtown Central Library building in 1906. The Alaska-Yukon-Pacific Exposition was a cultural and commercial fair held in 1909 to promote the growth of the Pacific Northwest, the trade opportunities with Pacific Rim nations, and showcased the City of Seattle. It

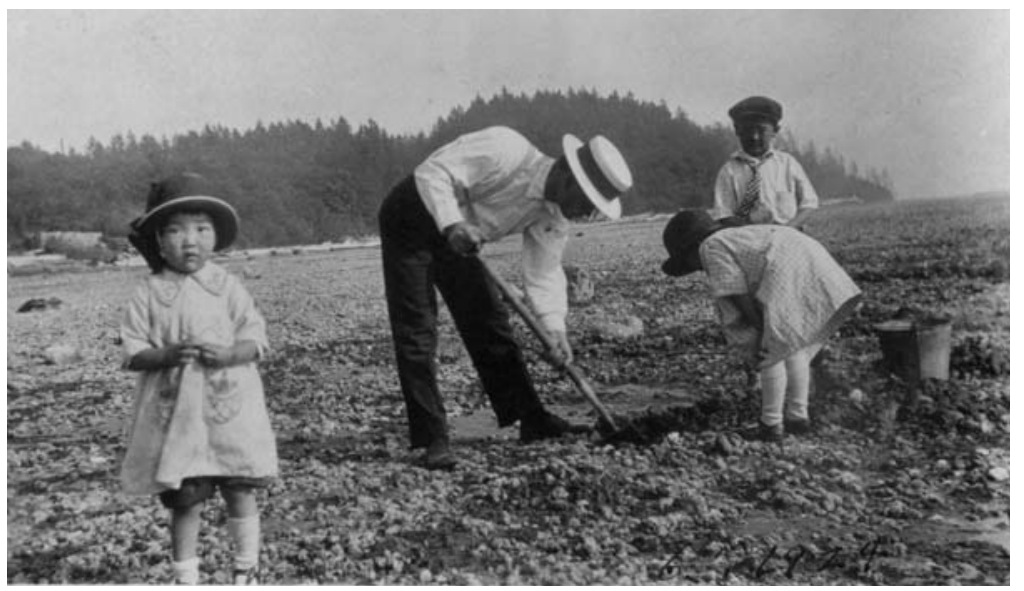

Family digging clams on Puget Sound, 1925. Wing Luke Asian Museum. of library service and technology. Highlights of the exhibit included the Ready Reference Center (with 730 of the best reference books) the "quest" space (individual study space with closed-circuit television and a telephone), and a UNIVAC computer that could print out quotations from "Great Books of the Western World." Forty-five years later the remains of the exhibition, the iconic Space Needle, the Pacific Science Center, the Monorail, and yes, the Elvis Presley film, "It Happened at the World's Fair," are reminders that for 184 days the city was the focus of the world. Seattle was "on the map" and its economic future, largely tied to the airplane manualso laid the architectural foundation of the current University of Washington. In 1926 Seattle became the first major city to elect a woman mayor, Bertha Landis, whose platform was the "municipal-housecleaning" of a corrupt city government. In 1940 a community activist named Pio de Cano successfully contested a state statute prohibiting noncitizens from owning property and became Seattle's first Filipino land owner. ${ }^{4}$

A milestone in the history of Seattle came in 1962 with the World's Fair "Century 21." Legend has it that the idea for hosting a World's Fair was hatched in 1955 by four businessmen at a martini luncheon. While organizers worked hard to make the fair a success, the coincidental launch of Sputnik and the beginning of the Space Age brought in record crowds to see science exhibits by NASA and IBM. Also participating at the World's Fair was ALA. The exhibit "LIBRARY-21" created a dynamic experience for fairgoers, which included the latest forms facturer The Boeing Company, seemed very promising.

Boeing was founded by William E. Boeing, a transplant from Detroit. Initially drawn to the area by the Northwest's thriving timber industry, Boeing decided in 1916 to sink his timber fortune into a new technology on the horizon: flight. By the onset of World War I, Boeing was turning out bi-planes for the nascent airmail industry and by World War II, Boeing, creator of the huge "Flying Fortress" B-17 Bomber, was a leading supplier of airplanes to the Allies.

During World War II Boeing was required to end its discriminatory hiring practices. As a result, more African Americans were drawn to Seattle, greatly increasing the population of its African American community over the following decade. By 1970 when Boeing unveiled the 747 , it became apparent that its hold on the market was nonetheless tenuous and substantial corporate downsizing followed. The repercussions of the "Boeing Bust" were 
felt throughout the area as families moved elsewhere in search of work. "Will the last person in Seattle please turn out the lights?" asked a prominent tongue-in-cheek billboard posted near the airport. Boeing eventually bounced back, and, to this day, Boeing's business successes and failures continue to affect the economic health of the region.

\section{The "new kids" on the block}

In 1971, just when Boeing was sending countless disappointed workers away, the first Starbucks coffee store was established in a funky little location across the street from Seattle's historic Pike Place Market. Founded by a writer, a history teacher, and an English teacher, Starbucks (named after Captain Ahab's doughty first mate) began by selling roasted beans and coffee supplies. Seattleites quickly grew addicted to the European-style dark roasted whole beans and later to the variety of espresso drinks Starbucks offered. While Starbucks is an undisputed giant in java throughout the world, locally, it helped generate a host of independent neighborhood coffee houses, many of which use organic shade grown beans.
An arguably greater global enterprise settled across the waters of Lake Washington in 1978 in the sleepy Seattle suburb of Bellevue. The company, originally called Micro-soft, changed the face of the Seattle region-and arguably the world of technology-forever. The life of Seattle native turned computer billionaire and philanthropist Bill Gates is legend. Back in the 1970s, home computers were pipe dreams at best. Bill Gates and co-founder Paul Allen maneuvered to create and market software for an emerging technology. The rest of the story is legend. By 1984 a still-young Gates was on the cover of Time magazine, and Seattle became a magnet for those hoping to make it big in the technology and Internet industries.

By 1999, a native New Yorker named Jim Bezos would also make headlines and change the Internet landscape. Bezos identified Seattle as a city where he could found his company: an online vending company named Amazon. Formed in 1994, when the Web was in its infancy and online commerce virtually unheard of, Amazon has thrived, survived the dot-com bust, and thrived again. Its service model, reader reviews, visual features, and personalized recommendations

\section{The greening of Seattle}

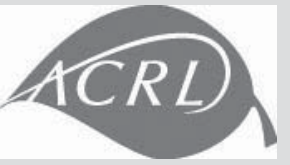

Seattle's unofficial title, "The Emerald City," has never been more apt. An early adopter of neighborhood recycling in the 1980s, Seattle was recently recognized as the nation's Greenest City by the real estate industry, owing to the number of environmentally friendly building projects it has underway. Green libraries are well represented: the Ballard Branch of the Seattle Public Library system was designed with a green roof, and Rem Koolhaas designed the Downtown Central Library for environmental sustainability.

In keeping with Seattle's commitment to environmentally conscious living, the 14th National ACRL Conference is the first to include a Green Committee in its planning. The committee's goal is to encourage envi- ronmental sustainability at the conference through education, information-sharing, and action.

Using input from the ACRL membership, the committee has developed a Green Pledge, asking participants to take advantage of Seattle's many "green" services and resources, especially in and around the Washington State Convention and Trade Center and conference hotels. The committee is also promoting sustainable choices_such as recycling, reducing waste, and selecting digital rather than paper handouts-by conference participants.

Look for more information about greening the 2009 ACRL National Conference in future articles in CERL News, on the ACRL Insider blog, and in your registration materials. 
changed user expectations and became an industry norm.

The "new kids" have had significant impact on the economic landscape of this area and have claimed their mark in Seattle history. Love them or hate them, there is no doubt that these three Seattle companies have also made their mark on our academic libraries. Microsoft has transformed the technological landscape of our campuses. Amazon has pushed publishers and book vendors to provide "in time" information on book availability, and has influenced the design of our OPACs. And Starbucks? In placing cafés in bookstores and selling books in its cafés, Starbucks has blurred the lines between commerce, coffee, and books, leading the way for the creation of a coffee commons in many of our libraries.

Along with Amazon, Google, and numerous other companies, Seattle is drawing in a new generation of innovators from all over the globe. In the summer of 2008 , based on the recent increase in high-tech jobs in the area, the American Electronics Association named Seattle the leading "cybercity" in the nation. Meanwhile, across Lake Washington, the quiet orchards and commuter suburbs of Redmond, Kirkland, and Bellevue have been transformed into hubs of population and technology as other companies (software and otherwise) have set up shop. From timber to technology, from politics to commercial ventures, Seattle has always pushed the edge.

\section{Visiting Seattle in 2009}

Start making your plans to attend the ACRL National Conference in Seattle in March 2009. The 1962 World's Fair credo was to "seek a common meeting place . . . a source of understanding and fuller knowledge that comes from working and building with others." Once again, Seattle will be that common meeting place.

We hope that the conference presents you with a new understanding of working and building with others and inspires you to engage, explore, and extend your knowledge of academic librarianship. ${ }^{7}$
To help you plan your trip, subsequent issues of CERL News will introduce you to the current City of Seattle. Upcoming articles will invite you to engage in the local music scene, explore diverse cultural offerings, and extend beyond the city limits to our natural surroundings. A final article will provide you with logistical information to help you get the most out of your visit. In the meantime, you can refer to the ACRL 14th National Conference Wiki for up-to-date information on the local restaurant scene, events, things to do, and more at wikis.ala.org/acrl/index.php /ACRL_14th_National_Conference_Wiki.

\section{Notes}

1. Murray Morgan, Century 21: The story of the Seattle World's Fair, 1962 (Seattle: Distributed by the University of Washington Press, 1963), 28.

2. Taylor Quintard, In Search of the Racial Frontier: African Americans in the American West, 1528-1990 (New York: W.W. Norton \& Company, 1998), 82.

3. U.S. National Park Service, "A Short History of Seattle," Klondike Gold Rush-Seattle Unit, www.nps.gov/klse/historyculture /index.htm.

4. Dorothy B. Fujita-Rony, American Workers, Colonial Power: Philippine Seattle and the Transpacific West, 1919-1941 (Berkeley: University of California Press, 2003), 89.

5. The Library and Information Networks of the Future (Chicago: American Library Association, 1963), 2.

6. Don Duncan, Meet Me at the Center: The Story of Seattle Center from the Beginnings, to the 1962 Seattle World's Fair, to the 21st Century (Seattle: Seattle Center Foundation, 1992), 55.

7. A final nod of thanks and appreciation to local historian the late Walt Crowley for pushing the edge. In 1999, Crowley along with Paul Dorpat created "HistoryLink.Org, The Online Encyclopedia of Washington State" www.historylink.org, which became the nation's first (and now largest) online encyclopedia of local and state history created expressly for the Internet. $\boldsymbol{n}$ 